\title{
Effects of Learning Styles and Locus of Control on the Decision- Making Styles of Leader Managers
}

\author{
Salim Akyürek ${ }^{1 *}$, Salih Guney ${ }^{1}$ \\ ${ }^{1}$ Istanbul Aydin Universitesi, Istanbul, TURKEY \\ Received 4 March 2018 - Revised 15 March 2018 - Accepted 15 March 2018
}

\begin{abstract}
This research aims to explain the effect of learning styles and locus of focus on the decision-making styles of leader managers. Therefore; firstly the learning styles, locus of control, decision-making styles were identified, then the relationship between the learning style and locus of control were analysed and the effects of learning styles and locus of control on the decision-making styles were investigated. Three scales were used for the research. The Decision-Making Styles Scale (DMSS) was developed by Scott and Bruce (1995) and adapted in Turkish by Taşdelen (2002). The Locus of Control Scale was developed by Dağ (2002) through using the Internal-External Locus of Control Scale of Rotter (1966) to identify the locus of control centre. Kolb Learning Style Inventory was developed by Kolb and translated and adapted to Turkish by Aşkar and Akkoyunlu (1993). The research covers the school principals, head vice principals and vice principals of state high schools of Ministry of Education located in İzmir. The findings were analysed in SPSS 21.0 and AMOS 20.0 programs. The results of research indicate that the leader managers mainly use the rational decision-making styles. Learning styles and locus of control are partially effective on the decision-making styles and the locus of control is effective on the learning style of participants.
\end{abstract}

Keywords: leadership, leader manager, learning style, locus of control, decision making style

\section{INTRODUCTION}

Human, as a social being, has the tendency to live together with other humans since its existence. The desire of humans to be together has brought the need to behave fair and protect the rights of others, organise, coordinate and manage the personal and social relations, business life in other words all living space. Humans required the existence of a group in order to fulfil their individual needs and reach their certain objectives and wanted to act together the group that they are a part of. Therefore, the individuals are now members of more than one group such as family, school, business environment, sports clubs, political parties that have an impact on their lives as well as having a significant role.

The concept of leadership has been considered as one of the important features of humans until today and has become one of the most used concepts in the daily and work life (Şahin, 2003:12). Thus, the leadership, which goes back to the history of humanity (Güney, 2015a:13) is one of the social and universal facts that is mysterious, still attracts interest, curiosity and is subject to various research and studies.

The following leading definitions aim to clarify the issue of leadership: Leadership is a quality, a characteristic and way of behaviour (Kotter, 2001). The essence of leadership is to impress people. Leadership is the relationship between a group of individuals who gathered around a common target, and an individual who determines the actions of such group of individuals (Tosun, 1992).

The manager is a concept that means the person, who manage and control (Y1lmaz, 2010:21). In the simplest sense, the person, who does the profession of management, is called the manager. Manager is a person, who works under an organisation, is authorized to plan and control the activities of people with the final responsibility (Güney,

(C) 2018 by the authors; licensee Modestum Ltd., UK. This article is an open access article distributed under the terms and conditions of the Creative Commons Attribution License (http://creativecommons.org/licenses/by/4.0/). $\square$ salim1806@gmail.com (*Correspondence) $\boldsymbol{\square}$ salihguney@aydin.edu.tr 


\section{Contribution of this paper to the literature}

- The results of the research indicate that the leader managers mainly tend to use the rational decision-making styles.

- The locus of control means the internal or external search of an individual about the reasons of positive and negative events in the life.

- It is identified that the learning styles of leader managers are not fully effective on the decision-making styles.

2015b). The manager is the individual that observes, leads and manage what people do in an organisation (Robbins et al., 2013:5).

There are various researches that discuss the differences between managers and leaders, which are mainly focused on their personalities, relations, styles to conduct and get people do business, attitudes towards their objectives and outcomes, attitudes in decision-making, perspectives and their source of power and their attitudes against change and risk.

When the leadership is defined, the main focal-point concepts are risk, change, renewal, influence, transformation, convince, trust, voluntarism, human-oriented etc., whereas for the managers, the main focus is on the concepts of authority, rules, hierarchy, enforcement, protection of status-quo. As can be seen, the differences between the manager and leader can be presented in different perspectives. The most important aspect is to understand that the manager and leader have different characteristics.

The difference between the leader and manager may resemble the difference between the phase of believing and originality. A leader manager is the person, who manages the organisation that he/she is responsible for, takes the organisation forward and have pioneer qualities (Ertürk, 2013:173). Thus, one of the crucial characteristics to look in a good manager is an effective leadership. In other words, the leader manager blends the features of a good manager and effective leader and reflects this on to the behaviours and practice.

\section{LEARNING STYLE}

The concept of learning style, which Rita Dunn started to discuss in 1960 for the first time, expresses a reflection of personal characteristics and choices of individuals and the differences between knowledge acquisition and processing (Bengiç, 2008:19; Boydak, 2015:3; Reid, 1987:89). The researchers that were interested in the features of students concentrated on the learning styles.

The learning style is one of the biological and developmental characteristics and one learning style may not be as effective for other person. A majority of activities of an individual has uniqueness to them, the learning style is personal too. It is possible to argue that although the learning styles may be similar among people, they are not exactly the same; and since the needs, desires and choices of each individual are different, a learning style of a person may not bring any superiority. In other words, each individual chooses an original path for learning.

\section{LOCUS OF CONTROL}

The locus of control is one of the subjects that still popular to study (Rotter, 1990:489). The concept was first used by the Phares (1957) and then become a part of psychology and social sciences as the back bone of Social Learning Theory presented by Rotter (1966) (Dağ, 1990:4).

The locus of control arisen as a result of expectation concept (Dağ, 2002:78) forms a vital aspect of personality (Rotter, 1966:1) and is among the main elements that shape the behaviours of people (Dönmez, 1983:38). The locus of control, as the main element for the theory of Rotter, reflects the beliefs of a person on his/her behaviours (Tekeli, 2010:35).

The locus of control is the effort of a person to control the beliefs, skills and abilities as well as events in the life. Additionally, it is related with the perception of who and what determines the behaviours and destiny. The locus of control reflects the belief towards the behaviours that have an impact on the events in the life. In other words, the locus of control means the internal or external search of an individual about the reasons of positive and negative events in the life. It is considered that if an individual believes that the positive or negative experiences are the results of his/her behaviours, that person has an internal locus of control, whereas if that person believes that the other elements (others, coincidence, luck, destiny, chance etc.) apart from himself/herself have an impact on the results, he/she has an external locus of control (Smith \& Mihans, 2009: 63). The people who perceive the reasons of experiences internally are expressed as people with internal locus of control, individuals perceiving the reasons out as people with external locus of control (Spector et al., 2002:454). 
The locus of control is a concept that determines the direction of life and aims to clarify the reason and means of individual choices. It is related with how much an individual has a control on the personal experiences.

\section{DECISION-MAKING STYLE}

The decision and activity of decision-making have a significant place in human life. People have to make decisions in every phase of their lives and as long as they are alive in order to continue their existence, since life can be defined as the chain of decisions. Therefore, people, groups, organisations and states have to make decisions continuously in almost every issue to solve their problems and continue their sustainability.

Decision-making that covers mental, physical and emotional processes means to choose and make preferences among different solutions, opportunities and means that will lead to targets (Eren, 2003:185). Due to its outcomes, decision-making is the activity of a person by oneself or together with others of perceiving and defining the problems, collecting information and data, developing solution alternatives, comparing these alternatives and choosing among them accordingly (Koçel, 2010:136). Decision- making can be explained as a process of choice (preference) covering all physical, emotional and intellectual activities which starts with the acknowledgement of a problem, then defining the problem, identification of criteria, assessment in accordance with the criteria, choosing the best among the options on the basis of assessment, implementation of choice and control and adjustment of implementation results. It is basically making the most appropriate and best choice in accordance with the situation.

Consequently, decision-making is a fact that can be found in every phase of life. Therefore, decision-making indicates a challenging process that is essential in individual and organisational life.

\section{METHODOLOGY}

The aim of this research is to discuss the effects of learning styles and locus of control of leader managers on their decision-making styles in a complete model. In this perspective, firstly the learning styles, locus of control and decision-making styles of leader managers were identified, then the relation between learning styles and locus of control was assessed and the effects of learning styles and locus of control on the decision-making style were analysed.

\section{Population and Sample}

The population of this research is the managers (school principals, head vice principals and vice principals) working in the state high schools of Ministry of Education located in İzmir. There are a total number of 1143 managers in 227 state high schools in İzmir. The sample of this research is 365 managers working in the high schools. The number of managers in the sample was calculated through the stratified sampling method and the scales were applied on the quorum number of managers in the selected schools (Büyüköztürk, 2009).

\section{Data Gathering, Method and Tools}

Three scales as Decision-Making Styles Scale (DMSS), Locus of Control Scale (LCS) and Kolb Learning Style Inventory (KLSI) were used in this study, which is a cross-sectional field study. In the data analysis, SPSS 21.0 and AMOS 20.0 programs were used.

\section{Data Analysis, Research Model and Hypothesis}

Within the scope of research, the construct validity was tested through the confirmatory factor analysis. In the confirmatory factor analysis, four different models are tested and the most fit and proper model is decided accordingly. In this perspective, Chi-Square Goodness of Fit, $\chi 2$ ), Root Mean Square Error of ApproximationRMSEA, Root Mean Square Residual-RMR, Goodness Of Fit Index-GFI, Incremental Fit Index (CFI) were used (Anderson \& Gerbing, 1984; Browne \& Cudeck, 1993; Kline, 2004; Kolb \& Kolb, 2009; Marsh, Balla, \& McDonald, 1988; Schumacker \& Lomax, 1996; Şimşek, 2007; Sümer, 2000). In order to express the inter-relations between variables and identify the direct and indirect impacts, the path analysis was conducted with Structural Equation Model (SEM). The statistical summary values regarding the fit of structural equation model were given in Table 1. 
Table 1. The Statistical Summary Values of the Structural Equation Model

\begin{tabular}{ccc}
\hline Modification Indices & Goodness of Fit & Acceptable Fitness \\
\hline$\chi^{2}$ modification test & Non - Significance levels & - \\
\hline$(\chi 2 / s d)$ & $\leq 3$ & $4-5$ \\
\hline RMR & $\leq 0.05$ & $0.06-0.08$ \\
\hline RMSEA & $\leq 0.05$ & $0.06-0.08$ \\
\hline GFI & $\geq 0.90$ & $0.89-0.85$ \\
\hline CFI & $\geq 0.90$ & $0.89-0.85$ \\
\hline
\end{tabular}

Source: Şimşek, 2007

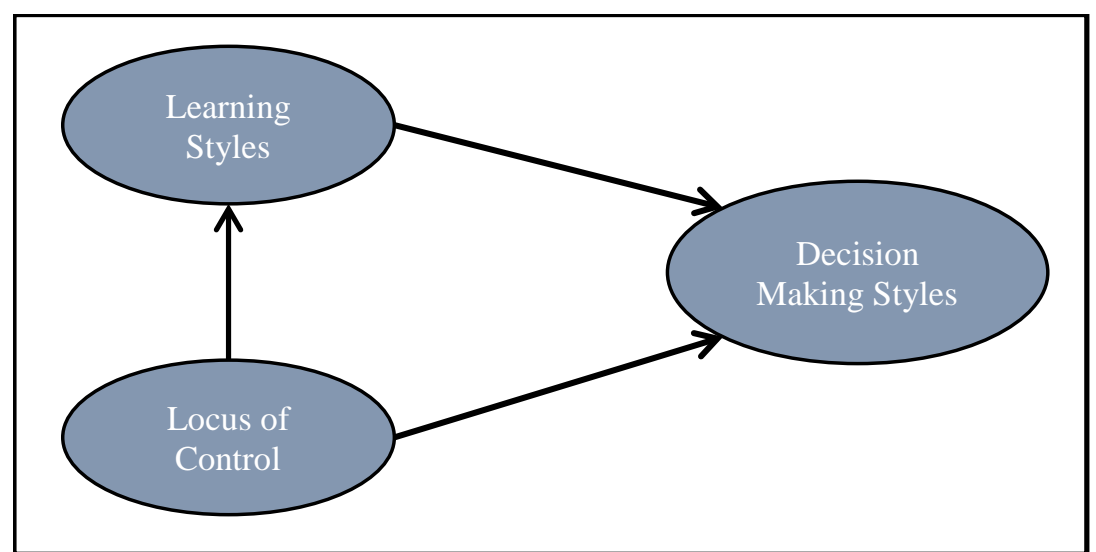

Figure 1. Research Model

The learning style of an individual is related with finding the most applicable solutions, ideas against a problem and using such knowledge in solution and decision-making skills (Kolb \& Kolb, 2008:46). The researchers indicate a relation between the decision-making style and learning-style. In a research conducted on consumers, Sproles and Sproles (1990) used the relation between learning style and decision-making style as a basis and noted that the decision-making style is a habit that can be learnt (Nas, 2010:44). Additionally, in the classification of learning styles, there are dimensions regarding decision-making and decision-making process. The individual learns from previous experiences and shape his/her decision-making style in accordance with the learning style. In consideration with such findings in the literature, the following hypothesis are developed.

H1: The learning style has a significant effect on the decision-making styles.

H2: The locus of control has a significant effect on the decision-making styles.

H3: The locus of control has a significant effect on the learning styles.

A model was developed in order to identify the relations between the variables that are discussed from a theoretic perspective (Figure 1). The model has three main variables as the decision-making style as the result variable given in the model, learning styles affecting this behaviour and locus of control. The research model developed on the basis of theoretic relation is given below.

\section{Findings}

\section{Findings on the effects of learning styles on the decision-making styles}

This part of research covers the correlation analysis findings for the relation between the learning styles of leader managers and decision-making styles, and effect between the variables.

The findings of the correlation analysis conducted to identify where there is any relation between the decisionmaking style and learning style of leader managers are given in Table 2. 
Table 2. Learning Styles-Decision-Making Styles / Correlational Analysis

\begin{tabular}{|c|c|c|c|c|c|c|c|c|c|c|}
\hline Factor & (1) & $(2)$ & (3) & (4) & (5) & $(6)$ & $(7)$ & $(8)$ & (9) & (10) \\
\hline 1. Rational (RDMS) & 1 & & & & & & & & & \\
\hline 2. İntutive (IDMS) & $-.238^{* *}$ & 1 & & & & & & & & \\
\hline 3. Dependent (DDMS) & $.141^{* *}$ & $.180^{* k}$ & 1 & & & & & & & \\
\hline 4. Avoidant (ADMS) & $-.235^{* *}$ & .044 & $.124^{*}$ & 1 & & & & & & \\
\hline 5. Spontabeous (SDMS & $-.321^{* \star}$ & $.165^{* *}$ & -.039 & $.383^{* *}$ & 1 & & & & & \\
\hline 6. Concrete Experience (CE) & $-.182^{* *}$ & $.225^{\star *}$ & .031 & $.286^{\star *}$ & $.364^{* *}$ & 1 & & & & \\
\hline 7.Abstract Conseptualization (AC) & .052 & $-.124^{*}$ & -.080 & $-.129^{\star}$ & $-.203^{* *}$ & $.365^{\star \star}$ & 1 & & & \\
\hline 8. Active Experience $(\mathrm{AE})$ & $.161^{* *}$ & .013 & -.008 & $-.232^{* *}$ & -.073 & $-.429^{* *}$ & $-.385^{* *}$ & 1 & & \\
\hline 9. Reflective Observation (RO) & -.037 & $-.106^{\star \star}$ & .070 & $.113^{* *}$ & $-.111^{\star *}$ & $-.226^{* *}$ & $-.215^{* *}$ & $-.333^{* \star}$ & 1 & \\
\hline Learning Styles & .093 & $-.201^{\star *}$ & .019 & $-.257^{* \star}$ & $-.217^{\star \star}$ & $-.559^{* \star}$ & $.441^{\star *}$ & $.140^{* *}$ & -.036 & 1 \\
\hline
\end{tabular}

Table 3. Learning Styles - Decision Making Styles / Structural Equation Model Analysis

\begin{tabular}{|c|c|c|c|c|c|c|}
\hline Model & $x^{2}$ & $\Delta \mathrm{x}^{2} / \mathrm{sd}$ & RMSEA & CFI & GFI & RMR \\
\hline Structural Model & 753.649 & 3.153 & 0.077 & 0.844 & 0.848 & 0.119 \\
\hline Modified Structural Model & 499.452 & 2.181 & 0.057 & 0.918 & 0.897 & 0.066 \\
\hline
\end{tabular}

The relations between the sub-dimensions of decision-making styles were analysed. In this perspective, there are positive, low significant relation $(\mathrm{r}=.141, \mathrm{p}<.001)$ between the rational decision-making style and dependent decision-making style and negative, low level and significant relation with other decision-making style $(\mathrm{r}=-.238$, $\mathrm{r}=-.235, \mathrm{r}=-.321 ; \mathrm{p}<.001)$. No relation was identified between the intuitive decision-making style and avoidant decision-making style $(\mathrm{r}=.044, \mathrm{p}<.05)$. There are positive low level and significant relations $(\mathrm{r}=.180, \mathrm{r}=.165, \mathrm{p}<.001)$ between the intuitive decision-making and dependent and spontaneous decision-making style. While there is a positive, low level significant relation $(\mathrm{r}=.124, \mathrm{p}<.05)$ between the dependant decision-making style and avoidant decision-making style, there is no relation with the spontaneous decision-making style $(\mathrm{r}=-.39, \mathrm{p}>.05)$.

In consideration with the learning style and decision-making styles; there is no significant relation between the rational decision-making and abstract conceptualisation and reflective observation dimensions $(r=.052, r=-.037$, $\mathrm{p}>.05)$, whereas the relation with the concrete experience is negative, low level and significant $(r=.182, \mathrm{p}<.05)$ and with active experience is positive, low level and significant $(\mathrm{r}=.161, \mathrm{p}<.05)$. There is no relation between the intuitive decision-making style and active experience $(\mathrm{r}=.013, \mathrm{p}>.05)$, there are positive, low level and significant $(\mathrm{r}=.225$, $\mathrm{p}<.001)$ relations between concrete experience and intuitive decision-making $(\mathrm{r}=.225, \mathrm{p}<.001)$, and negative, low level and significant relations $(\mathrm{r}=-, 124, \mathrm{r}=-.106, \mathrm{p}<.005)$ with the abstract conceptualisation and reflective observation $(\mathrm{r}=-\mathrm{-124}, \mathrm{r}=-.106, \mathrm{p}<.005)$. In accordance with the analysis concerning the relations between the avoidant decision-making style and sub-dimensions of learning styles, the relation between the avoidant decision-making style and concrete experience and reflective observation is positive, low level and significant $(r=.286, r=.113$, $\mathrm{p}<.001)$, and negative, low level and significant relations with abstract conceptualisation and active experience $(\mathrm{r}=-$ $.129, \mathrm{p}<.001, \mathrm{r}=-.232, \mathrm{p}<.05)$ in consideration with the relations between the spontaneous decision-making style and sub-dimensions of learning styles, there is no significant relation between the active experience and spontaneous decision-making $(\mathrm{r}=-.073, \mathrm{p}>.05)$, positive, low level and significant with concrete experience $(\mathrm{r}=.364, \mathrm{p}<.05)$, negative, low level and significant with abstract conceptualisation and reflective observation $(\mathrm{r}=-.203, \mathrm{r}=-.111$, $\mathrm{p}<.05)$. There is no significant relation between dependant decision-making and learning styles $(\mathrm{r}=.031, \mathrm{r}=-.080, \mathrm{r}=-$ $.008, \mathrm{r}=.070, \mathrm{p}>.05)$. On the other hand, there is no relation between the learning style and rational and dependent decision making style as one of the decision-making style $(\mathrm{r}=.93, \mathrm{p}>.05)$, there are significant negative relations $(\mathrm{r}=-$ $.201, \mathrm{r}=-.257, \mathrm{r}=-.559, \mathrm{p}<.05$ ) between intuitive, avoidant and spontaneous decision-making styles.

\section{Hypothesis test findings of learning style - decision-making style}

In order to identify the effect of learning styles of leader managers on the decision-making styles and test the hypothesis "H1: The learning style has a significant effect on the decision-making styles", a structural model was developed and path analysis was conducted.

The fit indices of structural model are given in Table 3. Pursuant to the fit indices, the other values other than the RMR are within the acceptable level. Therefore, the availability of higher fit value was looked through and the fit values obtained after the improvements in the model were identified as to be in the acceptable levels.

The modified structural model developed to test the hypothesis is given in the Figure 2 . The model is learning style oriented and the relations between the measurement items constituting the sub-dimensions of decisionmaking as well as the relations between the dimensions are also given in the figure. 


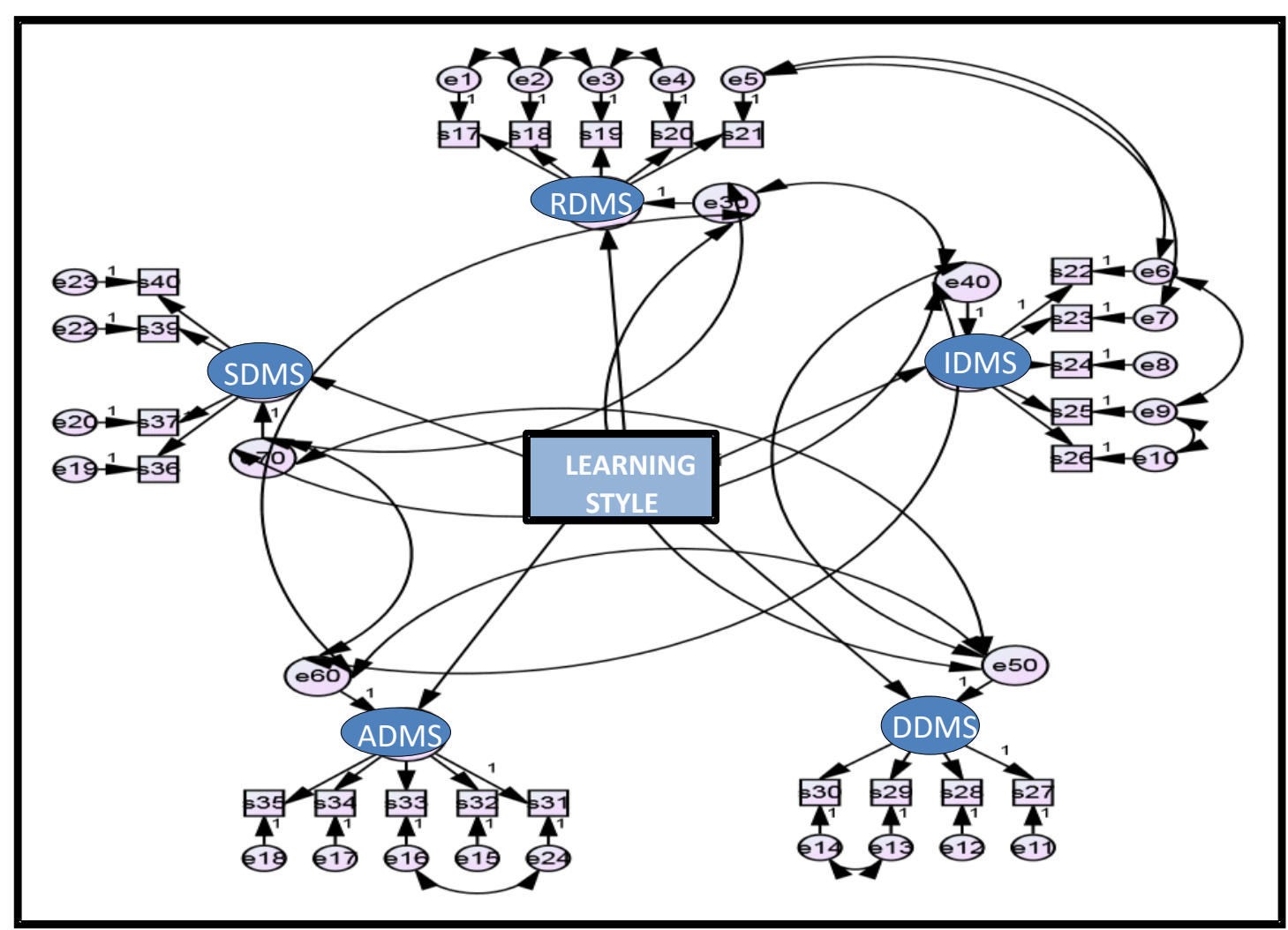

Figure 2. Learning Styles - Decision Making Styles / Structural Equation Model

Table 4. Learning Styles-Decision-Making Styles Path Analysis Results

\begin{tabular}{cccccc}
\hline Learning Styles & & Decision Making Styles & Regression Coefficients & S.E. & p \\
\hline Learning Styles & $\rightarrow$ & RDMS &, 033 &, 028 &, 232 \\
\hline Learning Styles & $\rightarrow$ & IDMS &,- 117 &, 040 &, 003 \\
\hline Learning Styles & $\rightarrow$ & DDMS &,- 007 &, 043 &, 874 \\
\hline Learning Styles & $\rightarrow$ & ADMS &,- 094 &, 025 &, 000 \\
\hline Learning Styles & $\rightarrow$ & SDMS &,- 178 &, 039 &, 000 \\
\hline${ }^{*} \mathrm{p}<.05$ & & & &
\end{tabular}

The structural model developed to identify the effect of learning style on the decision-making style was used and a path analysis was conducted through AMOS package program.

In accordance with the path analysis findings given in the Table 4, the learning style has not any significant effect on the rational and dependant decision-making styles $(\beta=.033, \beta=-.007 \mathrm{p}>.05)$ has a negative, low level and significant effect $(\beta=-.117, \beta=-.094, \beta=-.178, p<.05)$ on the intuitive, avoidant and spontaneous decision-making styles. Thus, $\mathrm{H} 1$ is partially is supported.

\section{Findings on the effects of locus of control on the decision-making styles}

In this part of the research, the correlation analysis findings regarding the relation between the locus of control and decision-making styles of leader managers, and the path analysis findings concerning the variables.

Table 5 indicates the correlation analysis findings performed to identify whether there is any relation between the decision-making styles and locus of control of leader managers. 
Table 5. Locus of Control-Decision Making Styles / Correlational Analysis

\begin{tabular}{|c|c|c|c|c|c|c|c|}
\hline Factor & (1) & (2) & (3) & (4) & $(5)$ & $(6)$ & (7) \\
\hline 1. RDMS & 1 & & & & & & \\
\hline 2. IDMS & $-.238^{* \star}$ & 1 & & & & & \\
\hline 3. DDMS & $.141^{\star *}$ & $.180^{\star \star}$ & 1 & & & & \\
\hline 4. ADMS & $-.235^{* *}$ & .044 & $.124^{*}$ & 1 & & & \\
\hline 5. SDMS & $-.321^{* \star}$ & $.165^{* \star}$ & -.039 & $.383^{* *}$ & 1 & & \\
\hline 6. ILC & $.491^{* *}$ & $.122^{*}$ & $.110^{*}$ & $-.239^{\star *}$ & .097 & 1 & \\
\hline 7. ELC & -.084 & $.329^{* \star}$ & .061 & $.231^{\star *}$ & .250 & -.055 & 1 \\
\hline
\end{tabular}

${ }^{*} p<.05^{* *}, p<.001^{*}$

Table 6. Locus of Control-Decision Making Styles / Structural Equation Model

\begin{tabular}{lcccccc}
\hline Model & $\boldsymbol{\Delta} \mathbf{\chi}^{\mathbf{2}}$ & $\boldsymbol{\Delta \mathbf { \chi } ^ { \mathbf { 2 } } / \mathbf { s d }}$ & $\mathbf{R M S E A}$ & $\mathbf{C F I}$ & $\mathbf{G F I}$ & $\mathbf{R M R}$ \\
\hline Structural Model & 1551.624 & 2.272 & 0.059 & 0.809 & 0.818 & 0.084 \\
\hline Modified Structural Model & 1252.332 & 1.909 & 0.050 & 0.869 & 0.851 & 0.074 \\
\hline${ }^{*} \mathrm{p}<0.05$ & & & & & &
\end{tabular}

In consideration with the relations between the sub-dimensions of locus of control and sub-dimensions of decision-making styles, there are positive, intermediate and significant relation $(r=.491, \mathrm{p}<.05)$ between the rational decision-making style and internal locus of control, negative, low and significant relation $(r=-.239, \mathrm{p}<.05)$ with the avoidant decision-making styles, and positive, low level and significant relation with the intuitive and dependant decision-making styles $(\mathrm{r}=.122, \mathrm{r}=.110, \mathrm{p}<.001)$. There is not any significant relation $(\mathrm{r}=.097, \mathrm{p}>.05)$ between the spontaneous decision-making style and internal locus of control.

Pursuant to the relations between the external locus of control and sub-dimensions of decision-making styles; there is not any relation between the external locus of control and rational, dependent and spontaneous decisionmaking styles ( $\mathrm{r}=-.084, \mathrm{r}=.061, \mathrm{r}=.250, \mathrm{p}>.05)$; whereas there are positive, low level and significant relations $(\mathrm{r}=.329$, $\mathrm{r}=.231, \mathrm{p}<.05$ ) between the external locus of control and intuitive and avoidant decision-making styles.

\section{Locus of control- decision-making style hypothesis test findings}

In order to identify the effect of learning styles of leader managers on the decision-making styles and test the hypothesis "H2: The locus of control has a significant effect on the decision-making styles", a structural model was developed and path analysis was conducted.

The fit indices of structural model are given in Table 6. Pursuant to the fit indices, the other values other than the RMSEA are not within the acceptable level. Therefore, the availability of higher fit value was looked through and the fit values obtained after the improvements in the model were identified as to be in the acceptable levels.

The modified structural model developed to test the hypothesis is given in the Figure 3 . The model is internal and external locus of control oriented and the relations between the measurement items constituting the subdimensions of decision-making as well as the relations between the dimensions are also given in the figure.

The structural model developed to identify the effect of learning style on the decision-making style was used and a path analysis was conducted through AMOS package program. In accordance with the path analysis findings given in the Table 7, the internal locus of control has not any effect on the dependent and spontaneous decisionmaking styles $(\beta=.456, \beta=-.751, p<.05)$ and have positive, high level significant effect $(\beta=2.274, \beta=1.193, p<0.05)$ on the rational and intuitive decision-making styles and have negative, high level and significant effect $(\beta=-.837$, $\mathrm{p}<0.05)$ on the avoidant decision-making style. The external locus of control has no significant effect $(\beta=-.083$, $\beta=.009, p>0.05)$ on the rational and dependent decision-making style, have positive, intermediate and significant effect $(\beta=.563, \beta=.454, p<0.05)$ on the intuitive and spontaneous decision-making style and have positive, low level and significant effect $(\beta=.190, p<0.05)$ on the avoidant decision-making style. Thus, H2 can be considered as partially supported. 


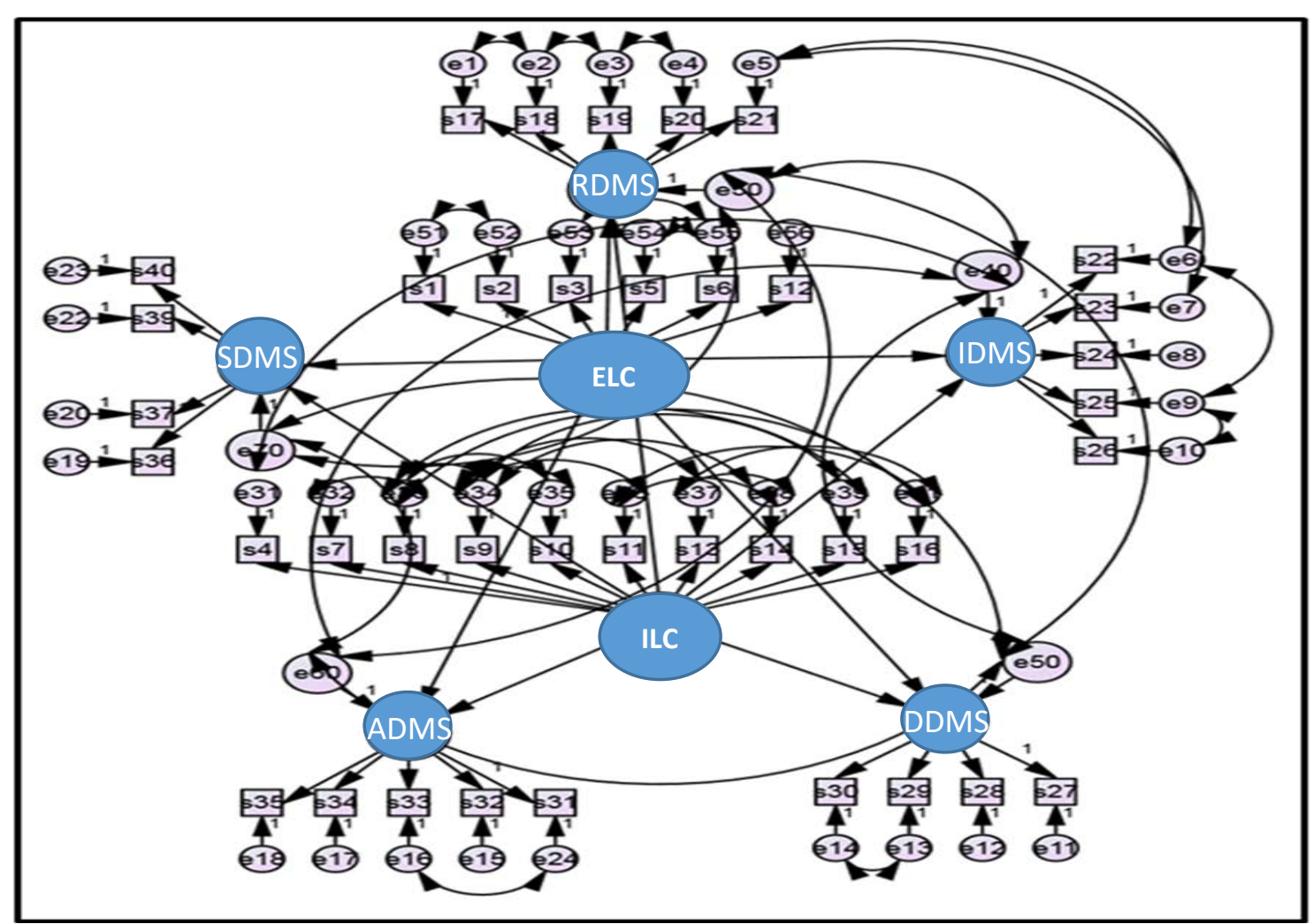

Figure 3. Locus of Control - Decision Making Styles /Structural Equation Model

Table 7. Locus of Control-Decision Making Styles - Path Analysis Results

\begin{tabular}{ccccccc}
\hline Locus of Control & & Decision Making Styles & Regression Coefficients & S.E. & p \\
\hline \multirow{3}{*}{ ILC } & $\rightarrow$ & RDMS & IDMS & 2,274 &, 95 &, 17 \\
\cline { 2 - 7 } & $\rightarrow$ & DDMS & 1,193 &, 558 &, 032 \\
\cline { 2 - 7 } & $\rightarrow$ & ADMS &, 456 &, 368 &, 215 \\
\cline { 2 - 7 } & $\rightarrow$ & SDMS &,- 837 &, 389 &, 032 \\
\hline \multirow{3}{*}{ ELC } & $\rightarrow$ & RDMS &,- 751 &, 412 &, 068 \\
\hline & $\rightarrow$ & IDMS &,- 083 &, 062 &, 177 \\
\hline & $\rightarrow$ & DDMS &, 563 &, 132 &, 113 &, 937 \\
\hline & $\rightarrow$ & ADMS &, 009 &, 065 &, 004 \\
\hline
\end{tabular}

${ }^{*} p<0.05$

\section{Findings on the effects of locus of control on the learning styles}

This part of research covers the correlation analysis findings for the relation between the locus of control and learning styles of leader managers, and effect between the variables.

The findings of correlation analysis performed to identify whether there is any relation between the locus of control and learning styles of leader managers are given in Table 8. No relation was found between the dimensions of locus of control. In general, pursuant to the analysis for the relations between the locus of control and learning style, there are positive, low level and significant relation $(\mathrm{r}=.114, \mathrm{p}<.05)$ between the learning style and internal locus of control; negative, low and significant relation $(\mathrm{r}=-.271, \mathrm{p}<.05)$ with the external locus of control. 
Table 8. Locus of Control - Learning Styles / Correlational Analysis

\begin{tabular}{lccccccc}
\hline Factor & $\mathbf{( 1 )}$ & $\mathbf{( 2 )}$ & $\mathbf{( 3 )}$ & $\mathbf{( 4 )}$ & $\mathbf{( 5 )}$ & $\mathbf{( 6 )}$ & $\mathbf{( 7 )}$ \\
\hline $1 . \mathrm{ILC}$ & 1 & & & & & & \\
\hline 2. ELC & -.055 & 1 & & & & & \\
\hline $3 . \mathrm{CE}$ & $-.140^{* *}$ & $.269^{*}$ & 1 & & & \\
\hline $4 . \mathrm{AC}$ & -.010 & $-.113^{* *}$ & $.365^{* *}$ & 1 & & \\
\hline $5 . \mathrm{AE}$ & $.210^{* *}$ & $-.148^{* *}$ & $-.429^{* *}$ & $-.385^{* *}$ & 1 & \\
\hline $6 . \mathrm{RO}$ & -.081 & -.016 & $-.226^{* *}$ & $-.215^{* *}$ & $-.333^{* *}$ & 1 & \\
\hline Learning Styles & $.114^{* *}$ & $-.271^{* *}$ & $-.559^{* *}$ & $.441^{* *}$ & $.140^{* *}$ & -.036 & 1 \\
\hline
\end{tabular}

${ }^{*} p<.05^{* *}, p<.001^{*}$

Table 9. Locus of Control-Learning Styles / Structural Equation Model

\begin{tabular}{lcccccc}
\hline Model & $\boldsymbol{\Delta} \mathbf{\chi}^{\mathbf{2}}$ & $\mathbf{\Delta \mathbf { x } ^ { \mathbf { 2 } } / \mathbf { s d }}$ & $\mathbf{R M S E A}$ & $\mathbf{C F I}$ & $\mathbf{G F I}$ & RMR \\
\hline Structural Model & 195.841 & 2.360 & 0.061 & 0.877 & 0.939 & 0.077 \\
\hline Modified Structural Model & 180.141 & 2.224 & 0.058 & 0.892 & 0.944 & 0.072 \\
\hline${ }^{*} \mathrm{p}<0.05$ & & & & & &
\end{tabular}

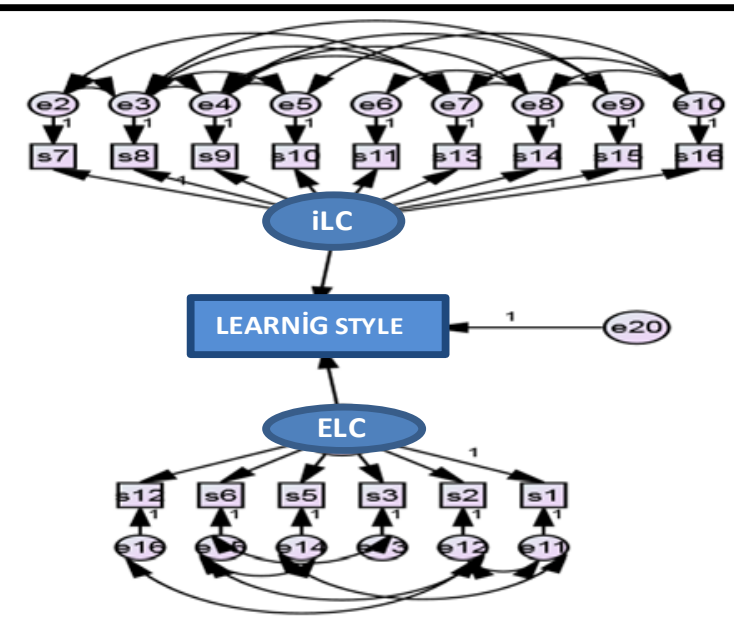

Figure 4. Locus of Control-Learning Styles / Structural Equation Model

In consideration with the relations between the internal locus of control and sub-dimensions of learning styles; there is a negative, low and significant relation $(\mathrm{r}=-.140, \mathrm{p}<.05)$ between concrete experience and internal locus of control, a positive, low and significant relation $(\mathrm{r}=.210, \mathrm{p}<.05)$ with the active experience; while there is not any significant relation with the reflective observation and abstract conceptualism dimensions $(r=-.081, r=-.010, p>.05)$.

Pursuant to the relations between the external locus of control and sub-dimensions of learning styles; there is a positive, low and significant relation $(\mathrm{r}=.269, \mathrm{p}<.001)$ between concrete experience and external locus of control, a negative, low and significant relation $(\mathrm{r}=-.113, \mathrm{p}<.05)$ with the abstract conceptualism, a negative, low and significant $(\mathrm{r}=-.148, \mathrm{p}<.05)$ relation with the active experience; while there is not any significant relation between the reflective observation and external locus of control $(r=-.016, p>.05)$.

\section{Locus of Control - Learning Style Hypothesis Test Findings}

In order to identify the effect of locus of control on the learning styles of leader managers and test the hypothesis "H3: The locus of control has a significant effect on the learning styles", a structural model was developed and path analysis was conducted.

The fit indices of structural model are given in Table 9. Pursuant to the fit indices, all values are within the acceptable level. However, the availability of higher fit value was looked through and the fit values obtained after the improvements in the model were identified as to be in the acceptable levels.

The modified structural model developed to test the hypothesis is given in the Figure 4 . The model is learning style oriented and the relations between the measurement items constituting the internal and external locus of control.

The structural model developed to identify the effect of locus of control on the learning style was used and a path analysis was conducted through AMOS package program (Table 10). 
Table 10. Locus of Control-Learning Styles Path Analysis Results

\begin{tabular}{|c|c|c|c|c|c|}
\hline \multicolumn{3}{|c|}{ Variables } & \multirow{2}{*}{$\begin{array}{c}\text { Regression Coefficients } \\
.392\end{array}$} & \multirow{2}{*}{$\begin{array}{l}\text { S.E. } \\
.027\end{array}$} & \multirow{2}{*}{$\begin{array}{c}\mathbf{p} \\
.006\end{array}$} \\
\hline ILC & $\rightarrow$ & Learning Styles & & & \\
\hline ELC & $\rightarrow$ & Learning Styles & -.543 & .042 & .000 \\
\hline
\end{tabular}

In accordance with the path analysis findings given in the Table 10, the internal locus of control has a positive effect $(\beta=.392, p<0.05)$ on the learning style and the external locus of control has a negative effect $(\beta=-.543, p<0.05)$. Therefore, $\mathrm{H} 3$ is supported.

\section{DISCUSSION}

Through the assessment of answers given to the scales, the leader managers mainly have the rational decisionmaking style $(n=200,54.79 \%)$ in terms of their decision-making styles, have internal locus of control in terms of locus of control aspect $(n=314.86 \%)$, have generally active experience from the learning style aspect (average $=35.12$, $\mathrm{s.d}=6.17$ ) and have abstract conceptualisation (average=31.08, s.d.=5.64) learning styles. The leader managers primarily process the information that they obtained through their abstract conceptualisation and active living skills and then act. The others can perform conceptual modelling as a result of combining abstract conceptualisation and reflective observation skills.

In terms of the effect of locus of control on the decision-making styles, the internal locus of control has not any effect on the dependent and spontaneous decision-making styles, have a positive effect on the rational and intuitive decision-making styles and a negative effect on the avoidant decision-making style; whereas the external locus of control does not have a significant effect on the rational and dependent decision-making styles and have positive effect on the intuitive, avoidant and spontaneous decision-making styles. Therefore, it can be concluded that $\mathrm{H} 2$ is partially supported. This finding is also compatible with Scott and Bruce (1995), Kaplan, Reneau, and Whitecotton (2001) and Yaşar (2011).

From the perspective of locus of control and learning styles, there is a negative significant relation between concrete experience and internal locus of control; positive significant relation with the active experience yet no significant relations between the internal locus of control and reflective observation and abstract conceptualisation. In general, there is no significant positive relation between the internal control and learning style. Pursuant to the relations between the external locus of control and learning styles, with abstract conceptualisation as negatively significant and negatively significant with the active experience; however there is not any significant relation between the reflective observation and external locus of control.

As a result of the path analysis conducted towards the effect of locus of control to the learning styles, the internal locus of control was found as having a positive effect on the learning styles, whereas the external locus of control as having a negative effect on the learning styles, which indicates that $\mathrm{H} 3$ is supported. This finding is consistent with the research results of Deryakulu (2002), Kormanik and Rocco (2009), De Hoogh and Den Hartog (2009) and Saracaloğlu and Yılmaz (2011). The positive characteristics of leader managers with the internal locus of control as being more open to the development (Yukl \& Mahsud,2010), having higher internal motives and showing easier guidance show that they do not have difficulties in implementing whatever they learn through experience. On the other hand, the leader managers with external locus of control- that the leaders were identified as being internal locus of control- can be considered as not being open to learning and development.

\section{CONCLUSION}

As a result, the learning styles and locus of control levels can be considered as having a partial effect on the decision-making styles. The obtained findings were found as compatible with the previous research. However, unlike the others, this study discussed the effect of learning styles on the decision-making style in an integrated model. In the consequence of this study, which contributed to the literature from this aspect, it is identified that the learning styles of leader managers are not fully effective on the decision-making styles. But this finding is limited with the sample of this research therefore this should not be considered for generalisation. Additionally, since the study is cross-sectional, the findings are limited with the time period of study. Similarly, due to the use of questionnaires as data collection method, it is possible to mention the social desirability. Due to these limitations, the researchers, who will study in this domain, should repeat the same model on similar or different samples. Moreover, the effect of other personal characteristics should be studied as the determinants of decision-making styles. 
The positive effect on the rational decision-making style can be explained in a such way that the leader managers with internal locus of control are more brave when it comes to taking the responsibility, and they have desire to work much freely. They believe in their qualifications and they are more into research with knowledge acquisition.

\section{REFERENCES}

Anderson, J. C., \& Gerbing, D. W. (1984). The effect of sampling error on convergence, improper solutions, and goodness-of-fit indices for maximum likelihood confirmatory factor analysis. Psychometrika, 49(2), 155-173.

Aşkar, P., \& Akkoyunlu, B. (1993). Kolb Öğrenme Stili Envanteri, Eğitim Ve Bilim, 17(87), 37-47.

Bengiç, G. (2008). İlköğretim 6. ve 7. Sını Öğrencilerinin Öğrenme Stilleri ile Sosyal Bilgiler Dersinde Başarıları Arasındaki İlişki (Unpublished Master Thesis), Pamukkale University Social Science Institute, Denizli.

Boydak, A. H. (2015). Öğrenme Stilleri, Beyaz Publication, 21. Press, İstanbul.

Browne, M. W., \& Cudeck, R. (1993). Alternative Ways of Assessing Model Fit. Sage Focus Editions, 154, 136-136.

Büyüköztürk, Ş. (2009). Sosyal Bilimler İçin Veri Analizi El Kitabı: İstatistik, Araştırma Deseni, SPSS Uygulamaları ve Yorumları. Ankara: Pegem Publication, 9. Press.

Dağ, İ. (1990). Kontrol Odağı, Stresle Başa Çıkma Stratejileri ve Psikolojik Belirti Gösterme İlişkileri (Unpublished Phd Thesis), Hacettepe Üniversitesi Sosyal Bilimler Enstitüsü, Ankara.

Dağ, İ. (2002). Kontrol Odağı Ölçeği (KOÖ): ölçek Geliştirme, Güvenirlik ve Geçerlik Çalışması, Türk Psikoloji Dergisi, 17(49), 77-90.

De Hoogh, A. H., \& Den Hartog, D. N. (2009). Neuroticism and locus of control as moderators of the relationships of charismatic and autocratic leadership with burnout. Journal of Applied Psychology, 94(4), 1058.

Deryakulu, D. (2002). Denetim odağı ve epistemolojik inançların öğretim materyalini kavramayı denetleme türü ve düzeyi ile ilişkisi. Hacettepe Üniversitesi Ĕ̆itim Fakültesi Dergisi, 22(22).

Dönmez, A. (1983). Denetim Odağ1 (Locus of Control) ve Çevre Büyüklüğü, Ankara University Educational Science Journal, 16(1), 37-47.

Eren, E. (2003). Yönetim ve Organizasyon: Çă̆daş ve Küresel Yaklaşımlar (6. Ed). İstanbul: Beta Yayınları.

Ertürk, M. (2013). İşletmelerde Yönetim ve Organizasyon (7. Ed). İstanbul: Beta Press Yayım Dağıtım.

Güney, S. (2015a). Davranış Bilimleri (9. Ed.). Ankara: Nobel Yayıncılık.

Güney, S. (2015b). Sosyal Psikoloji. Ankara: Nobel Yayınc1lı.

Kaplan, S. E., Reneau, J. H., \& Whitecotton, S. (2001). The effects of predictive ability information, locus of control, and decision maker involvement on decision aid reliance. Journal of Behavioral Decision Making, 14(1), 35-50.

Kline, R. B. (2004). Beyond Significance Testing: Reforming Data Analysis Methods in Behavioral Research. Washington, DC: American Psychological Association.

Koçel, T. (2010). İşletme Yöneticiliği (12. Ed.). İstanbul: Genişletilmiş Beta Yayınları.

Kolb, A. Y., \& Kolb, D. A. (2009). Experiential learning theory: A dynamic, holistic approach to management learning, education and development. The SAGE handbook of management learning, education and development, 42-68.

Kormanik, M. B., \& Rocco, T. S. (2009). Internal versus external control of reinforcement: A review of the locus of control construct. Human Resource Development Review, 8(4), 463-483. https:/ / doi.org/10.1177/1534484309342080

Kotter, J. P. (2001). What leaders really do. Harvard business review, 79(11).

Marsh, H. W., Balla, J. R., \& McDonald, R. P. (1988). Goodness-of-fit indexes in confirmatory factor analysis: The effect of sample size. Psychological bulletin, 103(3), 391.

Nas, S. (2010). Karar Verme Stillerine Bilimsel Yaklaşımlar. Dokuz Eylül Üniversitesi Denizcilik Fakültesi Dergisi, 2(2), 43-65.

Phares, E. J. (1957). Expectancy Changes İn Skill And Chance Situations. The Journal Of Abnormal And Social Psychology, 54(3), 339-342. https:/ / doi.org/10.1037/h0045684

Reid, J. M. (1987). The learning style preferences of ESL students. TESOL quarterly, 21(1), 87-111. https:/ / doi.org/10.2307/3586356

Robbins, S. P., Decenzo, D. A., \& Coulter, M. (2013). Yönetimin esasları (A. Öğüt, Trans.). Ankara: Nobel.

Rotter, J. B. (1966). Generalized expectancies for internal versus external control of reinforcement. Psychological monographs: General and applied, 80(1), 1. 
Rotter, J. B. (1990). Internal versus external control of reinforcement: A case history of a variable. American psychologist, 45(4), 489.

Şahin, S. (2003). Okul müdürlerinin liderlilk stilleri ile okul kültürü arasındaki ilişkiler (Doctoral dissertation). DEÜ Eğitim Bilimleri Enstitüsü.

Saracaloğlu, A. S., \& Yılmaz, S. (2011). Öğretmen adaylarının eleştirel düşünme tutumları ile denetim odaklarının incelenmesi. İlköğretim Online, 10(2).

Schumacker, R. E., \& Lomax, R. G. (2004). A beginner's guide to structural equation modeling. London: Routledge.

Scott, S. G., \& Bruce, R. A. (1995). Decision making style: The development of a new measure. Educational and Psychological Measurement, 55(5), 818-831.

Şimşek, Ö. F. (2007). Yapısal eşitlik modellemesine giriş: Temel ilkeler ve LISREL uygulamaları. Ankara: Ekinoks, 315-337.

Smith, C. A., \& Mihans, R. J. (2009). Raising issues of student locus of control: Beginning a longitudinal study. Research in Education, 81(1), 63-65.

Spector, P. E., Cooper, C. L., Sanchez, J. I., O’Driscoll, M., Sparks, K., Bernin, P., ... Shanfa, Y. (2002). Locus Of Control and Well-Being At Work: How Generalızable Are Western Findings? Academy of Management Journal, 45, 453-466.

Sproles, E. K., \& Sproles, G. B. (1990). Consumer decision-making styles as a function of individual learning styles. Journal of Consumer Affairs, 24(1), 134-147.

Sümer, N. (2000). Yapısal eşitlik modelleri: Temel kavramlar ve örnek uygulamalar. Türk psikoloji yazıları, 3(6), 4974.

Taşdelen, A. (2002). Öğretmen Adaylarının Farklı Psikososyal Değişkenlere Göre Karar Verme Stilleri (Unpublished Doctoral Thesis), Dokuz Eylül Üniversitesi Eğitim Bilimleri Enstitüsü, İzmir.

Tekeli, Ş. G. (2010). Lise son sını öğrencileri ile üniversite öğrencileri arasında bir karşılaştırma: akademik benlik yeterliği, denetim odă̆̆, stresle başa çıkma ve problem çözme becerisi (Unpublished Doctoral Thesis). University of Ankara, Ankara, Turkey.

Tosun, K. (1992). İşletme Yönetimi. Ankara: Savaş Yayınları.

Yaşar, O. (2011). Karar verme stili öncülleri: Savunma sanayinde bir araştırma (Unpublished Doctoral Thesis). Kara Harp Okulu, Sosyal Bilimler Enstitüsü, Ankara.

Yılmaz, H. (2010). Stratejik Liderlik (2. Ed.), Kum Saati Yayın Dağıtım, İstanbul.

Yukl, G., \& Mahsud, R. (2010). Why flexible and adaptive leadership is essential. Consulting Psychology Journal: Practice and Research, 62(2), 81. https://doi.org/10.1037/a0019835

\section{http://www.ejmste.com}

